\title{
Influence of stage of maturity of grass silages on protein digestion and microbial protein synthesis in the rumen
}

\author{
M.W. BOSCH ${ }^{1,2}$, J. VAN BRUCHEM ${ }^{2}$, L.J.G.M. BONGERS ${ }^{2}$ AND S. TAMMINGA ${ }^{1}$ \\ 1 Department of Animal Nutrition, Wageningen Agricultural University, \\ Haagsteeg 4, NL-6708 PM, Wageningen, The Netherlands \\ 2 Department of Human and Animal Physiology, Wageningen Agricultural University, \\ Haarweg 10, NL-6709 PJ Wageningen, The Netherlands
}

Received 13 October 1993; accepted 12 March 1994

\begin{abstract}
In four change-over experiments, wilted grass silages, differing in growth stage at harvesting and as a consequence in cell wall content, were fed ad libitum to dairy cows in early and late lactation.

Ruminal degradation rate of the crude protein fraction of the silages was investigated using nylon bag incubations. No significant relation between the degradation rate $\left(\% \mathrm{~h}^{-1}\right)$ and the cell wall content of the silages was found. The soluble and undegradable fractions of the crude protein both increased with an increase in silage cell wall content. The soluble fraction was more closely related to dry matter content and date of harvesting than to cell wall content of the silages. The fraction of dietary protein escaping rumen fermentation increased with cell wall content.

In duodenal protein, the fraction originating from the diet, estimated using amino acid profiles of dietary, microbial and duodenal protein, decreased with cell wall content.
\end{abstract}

Keywords: grass silages, protein digestion, microbial protein

\section{Introduction}

Feeding grass products with a high nitrogen $(\mathrm{N})$ content to dairy cows usually results in considerable $\mathrm{N}$ losses. One way to reduce these losses is by reducing the CP to carbohydrate ratio (Van Vuuren \& Meijs, 1987). This is possible by a reduction in N fertilization or by feeding/harvesting more mature grass or both. The latter is particularly the case if grass with low $\mathrm{N}$ fertilization is harvested at same DM yield as high-N grass. Ensiling the grass at a more mature stage results not only in lower CP contents, but normally also reduces its digestibility (Van Soest, 1982).

The protein entering the small intestine of ruminants consists of microbial protein synthesized in the rumen, dietary protein which escaped rumen fermentation and endogenous protein. The digestibility of this protein mixture in the small intestine determines the amount of amino acids available for the ruminant. 
The amount of feed protein escaping rumen fermentation can be estimated from the degradability of feed protein measured with the nylon-bag technique (Mehrez \& Ørskov, 1977), and the rate of passage of the particulate phase to the lower gut.

Different methods to estimate the fraction of duodenal microbial protein synthesized in the rumen are possible e.g. with markers specific for microbial protein (DAPA, nucleic acids, ${ }^{35} \mathrm{~S},{ }^{15} \mathrm{~N}$ ), or on the basis of the amino acid profiles (AAP) of the different protein sources (Van Bruchem et al., 1985).

In four experiments, in which the effect of chemical composition of grass silages on intake and digestion processes was investigated (Bosch et al., 1992a), CP degradation in the rumen was determined using the nylon-bag method. In addition, the influence of the chemical composition of the silages on the fractions of microbial and dietary protein was estimated. For reason of an appropriate recycling of nutrients within the system, sustainable livestock production aims at an increased utilization of homegrown feeds. In the present study rumen $\mathrm{N}$ availability is assessed relative to the quantity of $\mathrm{N}$ incorporated in rumen microbes, and hence, to the quantity of organic matter degraded in the rumen. Nett $\mathrm{N}$ losses in the rumen are aimed to be kept at a minimum and in association with this $\mathrm{N}$ emission into the environment.

\section{Materials and methods}

In four change-over experiments, grass silages were fed ad libitum to dairy cows. In each of the experiments two silages were fed, supplemented with 7 (Exps. 2 (silage G1 and G2) and 4 (silage G3 and G5)) or 1 (Exps. 1 (silage G1 and G2) and 3 (silage G3 and G4)) kg of concentrates, in early and late lactation, respectively. Each experiment consisted of two experimental periods of five weeks, preceded by adaptation periods of three weeks. All cows were fitted with a rumen canmula, and, except for two animals in Exp. 4, also with a T-cannula in the proximal duodenum.

The grasses were harvested at different growth stages, resulting in silages differing in chemical composition. The composition of the silages and the concentrates is given in Table 1.

The silages were supplied three times a day; at $7.00,15.00$ and $23.00 \mathrm{~h}$, and the concentrates were fed at $14.45 \mathrm{~h}(1 \mathrm{~kg})$ or at 6.45 and $14.45 \mathrm{~h}$ (two portions of 3.5 $\mathrm{kg})$. The experimental design is described in detail by Bosch et al. (1992a). Intake and whole tract digestibility figures of organic matter (OM) and $\mathrm{CP}$ are given in Table 2.

The degradation rate $\left(\mathrm{k}_{d}, \% \mathrm{~h}^{-1}\right)$ and the rumen undegradable $\left(\mathrm{f}_{R}, \%\right)$ fraction of the $\mathrm{CP}$ of the silages were measured by means of nylon bag incubations, according to the procedure described by Bosch et al. (1992a), but without a lag time in the degradation model. Bags were incubated in the rumen for $3,5,8,16,24,48,72$ and $336 \mathrm{~h}$, the latter to determine $f_{R}$. After incubation the bags were washed twice with cold water in a washing machine. The soluble fraction $\left(f_{\mathrm{S}}, \%\right)$ was determined after the washing procedure without previous incubation in the rumen. The latter samples, as well as the $336 \mathrm{~h}$ incubation samples, were pooled per silage, so one water soluble and one undegradable fraction was determined per silage. 
Table 1. Chemical composition of the five grass silages and the concentrates. $\mathrm{DM}=\mathrm{dry}$ matter, $\mathrm{OM}=$ organic matter, $\mathrm{CP}=$ crude protein, $\mathrm{NDF}=$ neutral detergent fibre.

\begin{tabular}{|c|c|c|c|c|c|c|}
\hline & G1 & G2 & G3 & G4 & G5 & Concentrates $^{1}$ \\
\hline $\begin{array}{l}\text { DM (\%) } \\
\text { in DM }\end{array}$ & 59.4 & 54.3 & 60.8 & 38.7 & 55.0 & 88.1 \\
\hline OM (\%) & 86.8 & 90.8 & 89.8 & 92.5 & 92.6 & 90.4 \\
\hline CP (\%) & 21.3 & 19.6 & 20.9 & 11.9 & 11.2 & 18.2 \\
\hline NDF (\%) & 44.6 & 54.7 & 54.8 & 64.1 & 67.3 & 28.6 \\
\hline cellulose (\%) & 23.4 & 29.3 & 25.8 & 33.6 & 32.9 & 12.4 \\
\hline hemicellulose (\%) & 19.1 & 22.0 & 26.1 & 25.9 & 26.9 & 14.5 \\
\hline lignin (\%) & 2.1 & 3.4 & 2.9 & 4.6 & 7.5 & 1.7 \\
\hline $\mathrm{NH}_{3}{ }^{2}$ & 4 & 6 & 2 & 10 & 5 & \\
\hline harvest date & $\begin{array}{l}\text { 2 July } \\
1985\end{array}$ & $\begin{array}{l}28 \text { May } \\
1985\end{array}$ & $\begin{array}{l}12 \text { August } \\
1986\end{array}$ & $\begin{array}{l}23 \text { June } \\
1986\end{array}$ & $\begin{array}{l}\text { 6 July } \\
1987\end{array}$ & \\
\hline
\end{tabular}

'mean of four experiments

${ }^{2} \mathrm{NH}_{3}-\mathrm{N}$ as a $\%$ of total $\mathrm{N}$

Using the nylon bag degradation characteristics, and assuming a fractional passage rate from the rumen $\left(\mathrm{k}_{\mathrm{p}}, \% \mathrm{~h}^{-1}\right)$, the fraction of silage protein escaping rumen fermentation $\left(\mathrm{f}_{\mathrm{E}}\right)$ can be calculated according to the equation:

$$
f_{E}=f_{R}+\left(100-f_{S}-f_{R}\right) *\left(k_{p} /\left(k_{d}+k_{p}\right)\right)
$$

During $72 \mathrm{~h}$, duodenal samples (approximately $0.25 \mathrm{l}$, after collecting first 11 which was returned into the fistula after sampling) were taken every two hours, pooled per cow per week, freeze dried, ground through a $1 \mathrm{~mm}$ screen and stored till further analysis.

From rumen liquid samples, taken from the ventral rumen sac during the first two days of these periods at $7.00,9.00,11.00$ and $13.00 \mathrm{~h}$, bacteria were isolated by differential centrifugation ( 550 and $70000 \mathrm{~g}$ ) with a MSE superspeed 65 centrifuge at $4^{\circ} \mathrm{C}$. The pellet was washed twice with a buffer solution according to the method described by Meyer et al. (1967), and then freeze dried, ground and stored till analysis.

Rumen evacuations were done during the last weeks of the experimental periods as described by Bosch et al. (1992b). Rumen liquid and particulate contents were sampled before returning into the rumen.

The silages, concentrates, rumen bacteria and ruminal and duodenal contents were analysed for nitrogen $(\mathrm{N})$ and individual amino acids.

Nitrogen was determined according to the Kjeldahl method (micro-Kjeldahl for the rumen bacteria) with $\mathrm{K}_{2} \mathrm{SO}_{4}$ and $\mathrm{HgO}$ as catalysts. The individual amino acids were determined using a Biotronic LC 6000 automatic amino acid analyser. Samples were hydrolysed under reflux for $22 \mathrm{~h}$ with $\mathrm{HCl}\left(6 \mathrm{~mol} \mathrm{l}^{-1}\right)$ at $110^{\circ} \mathrm{C}$. After formic acid oxidation (Moore, 1963), the sulphur containing amino acids, methionine and cystine, were determined as methionine sulphone and cysteic acid, respectively. Tryptophan was not determined. 
M.W. BOSCH, J. VAN BRUCHEM, L.J.G.M. BONGERS AND S. TAMMINGA

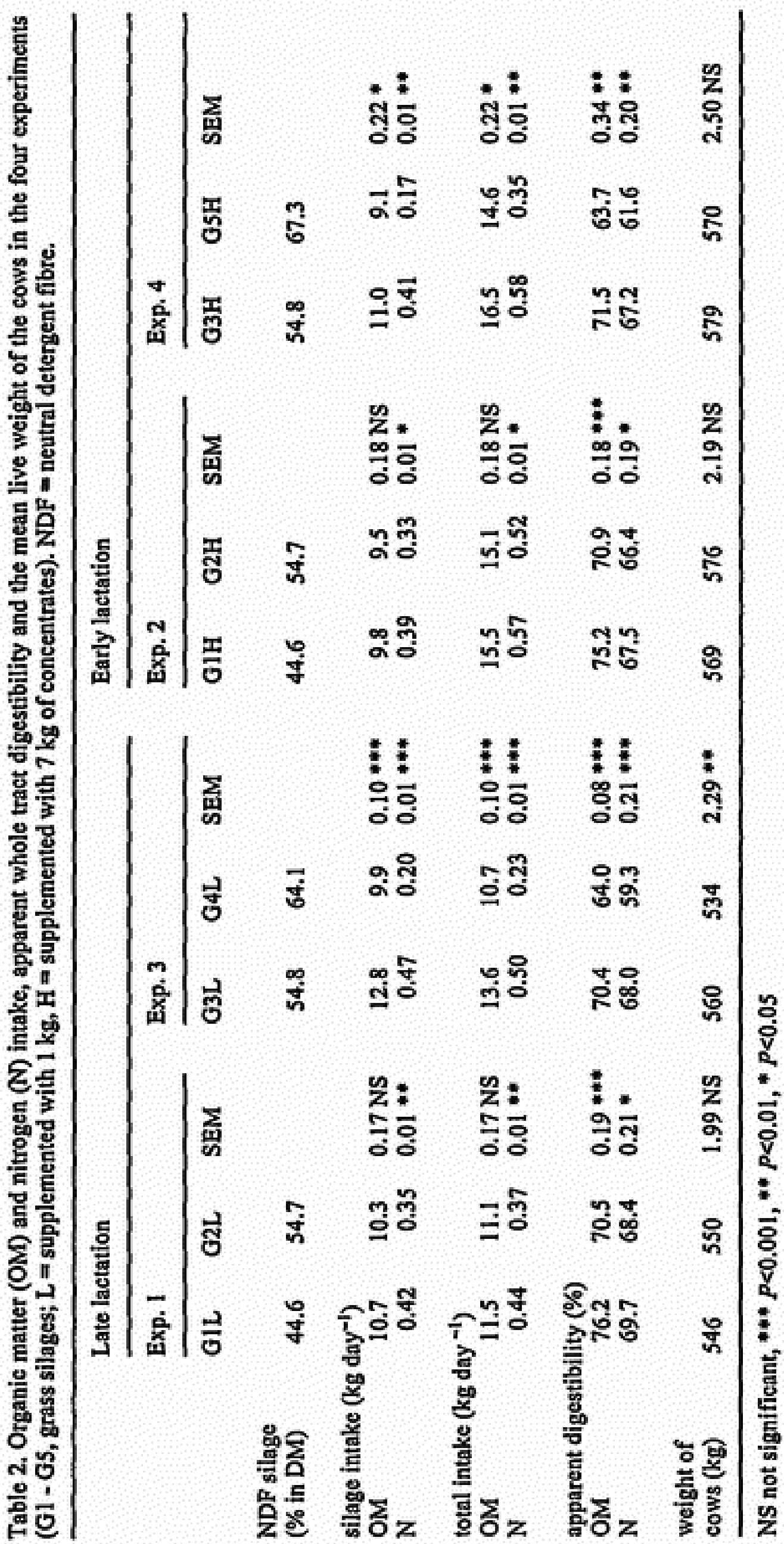


The fraction of crude protein entering the duodenum originating from the diet, was estimated, based on the amino acid profile (AAP) of dietary, microbial and duodenal proteins. Dietary and microbial proteins were mixed by a computerized iterative procedure in such proportions that the computed AAP matched best the actual AAP of duodenal protein, on the basis of minimizing the objective function (Van Bruchem et al., 1985) :

$$
\sum_{A A=1}^{17}\left(1-\mathrm{AA}_{\text {computed }} / \mathrm{AA}_{\text {actual }}\right)^{2}
$$

In addition, the fraction of protein in the rumen, consisting of dietary protein was calculated according to the same method.

Data were analysed statistically using the Anova procedure of the SPSS/PC+ statistical package (SPSS Inc., 1988) as described by Bosch et al. (1992a).

\section{Results}

The degradation characteristics of the $\mathrm{CP}$ fraction of the silages are given in Table 3 . The soluble $\left(f_{S}\right)$ and the undegradable $\left(f_{R}\right)$ fractions both increased with the cell wall content of the silages, except for the $f_{S}$ of silage G3. Silage G3 had a lower soluble protein fraction as compared to the other silages. The $k_{d}$ was significantly higher $(P<0.05)$ for the low cell wall silages in Exps. 1, 2 and 3. There was a negative, though not significant relation between $k_{d}$ and the neutral detergent fibre (NDF) content of the silages $(r=-0.68)$.

The fractions of dietary protein escaping rumen fermentation were calculated using equation (1), assuming a $\mathrm{k}_{\mathrm{p}}$ of $4.5 \% \mathrm{~h}^{-1}$ and a $\mathrm{k}_{\mathrm{p}}$ of $3.0 \% \mathrm{~h}^{-1}$, respectively. The first value is being used in the Netherlands protein evaluation system, and the latter value was estimated by Bosch (1991) for different grass silages as the fractional decline in rumen indigestible organic matter pool with time after feeding.

The thus calculated $f_{E}$ values are given in Table 4 . With an increase in cell wall content, $f_{E}$ seemed to increase. For the higher $k_{p}\left(4.5 \% h^{-1}\right.$ vs $\left.3 \% h^{-1}\right)$, the differences became smaller.

The AAP of the protein consumed (silage + concentrates), and the AAP of ruminal, microbial and duodenal proteins are given in Tables 5A and 5B. These AAP's were used to calculate the fractions of duodenal and ruminal protein originating from dietary and microbial proteins. The results are given in Table 6. No significant $(P>0.05)$ differences in the fractions of protein in the duodenum originating from the diet were found, except for Exp. 3 , in which significantly $(P<0.001)$ lower figures for silage G4 were observed than for silage G3. This extremely low proportion of dietary protein in rumen and duodenum has presumably to be regarded as an artefact, and was therefore exempted from further considerations. Though not significantly, within experiments a lower fraction of dietary protein in the duodenum was measured for the silage with the highest cell wall content. The fraction of protein in the rumen consisting of dietary protein is also given in Table 6. In Exps. 2, 3 and 4, low- 
Table 3. The soluble $\left(f_{S}, \%\right)$ and undegradable $\left(f_{R}, \%\right)$ crude protein fractions of silages (GI-G5) fed supplemented with I (L) or 7 (H) $\mathrm{kg}$ of concentrates per day, and the rate of crude protein degradation $\left(\mathrm{k}_{\mathrm{d}} \% \mathrm{~h}^{-1}\right)$.

\begin{tabular}{|c|c|c|c|c|c|c|c|c|c|c|c|c|}
\hline & \multicolumn{6}{|c|}{ Late lactation } & \multicolumn{6}{|c|}{ Early lactation } \\
\hline & \multicolumn{3}{|c|}{ Exp. 1} & \multicolumn{3}{|c|}{ Exp. 3} & \multicolumn{3}{|c|}{ Exp. 2} & \multicolumn{3}{|c|}{ Exp. 4} \\
\hline & GIL & G2L & SEM & G3L & G4L & SEM & G1H & G2H & SEM & G3H & GSH & SEM \\
\hline $\begin{array}{l}\text { NDF silage } \\
\text { (\% in DM) }\end{array}$ & 44.6 & 54.7 & & 54.8 & 64.1 & & 44.6 & 54.7 & & 54.8 & 67.3 & \\
\hline$f_{S}$ & 49.7 & 52.4 & & 41.6 & 56.4 & & 49.7 & 52.4 & & 41.6 & 57.3 & \\
\hline$f_{R}$ & 5.9 & 10.0 & & 9.4 & 18.1 & & 5.9 & 10.0 & & 9.4 & 24.4 & \\
\hline$k_{d}$ & 4.81 & 4.04 & $0.13 *$ & 5.19 & 4.30 & $0.13 *$ & 6.42 & 5.48 & $0.13 *$ & 4.53 & 3.96 & $0.21 \mathrm{NS}$ \\
\hline
\end{tabular}

NS not significant, $* P<0.05$

Table 4. Estimated fractions of silage protein escaping rumen fermentation (fE, \%) assuming fractional passage rates $\left(\mathrm{kp}, \% \mathrm{~h}^{-1}\right)$ of 3 and $4.5 \%$, respectively. $(\mathrm{L}=$ silage fed supplmented with $1 \mathrm{~kg}, \mathrm{H}=$ silage fed supplemented with $7 \mathrm{~kg}$ of concentrates per day).

\begin{tabular}{|c|c|c|c|c|c|c|c|c|}
\hline & \multicolumn{4}{|c|}{ Late lactation } & \multicolumn{4}{|c|}{ Early lactation } \\
\hline & \multicolumn{2}{|c|}{ Exp. 1} & \multicolumn{2}{|c|}{ Exp. 3} & \multicolumn{2}{|c|}{ Exp. 2} & \multicolumn{2}{|c|}{ Exp. 4} \\
\hline & GIL & G2L & G3L & G4L & GIH & G2H & G3H & G5H \\
\hline $\begin{array}{l}\text { NDF silage } \\
(\% \text { in DM) }\end{array}$ & 44.6 & 54.7 & 54.8 & 64.1 & 44.6 & 54.7 & 54.8 & 67.3 \\
\hline $\begin{array}{l}f_{E} \\
k_{p}=3 \% h^{-1}\end{array}$ & 19.0 & 23.4 & 24.4 & 26.6 & 15.7 & 18.0 & 25.2 & 30.1 \\
\hline $\begin{array}{l}f_{E} \\
k_{p}=4.5 \% h^{-1}\end{array}$ & 23.0 & 27.0 & 29.0 & 29.1 & 19.1 & 20.9 & 29.8 & 31.8 \\
\hline
\end{tabular}

er bacterial protein fractions for the lower cell wall silages than for the higher cell wall silages were calculated. In Exp. 1, however, the opposite was found. A higher fraction of protein in the rumen was estimated to originate from the diet for the low cell wall silage (GIL).

\section{Discussion}

During incubation in nylon bags in the rumen the contents of the bags become initially contaminated with microbial N, which, according to Nocek \& Grant (1987), is 


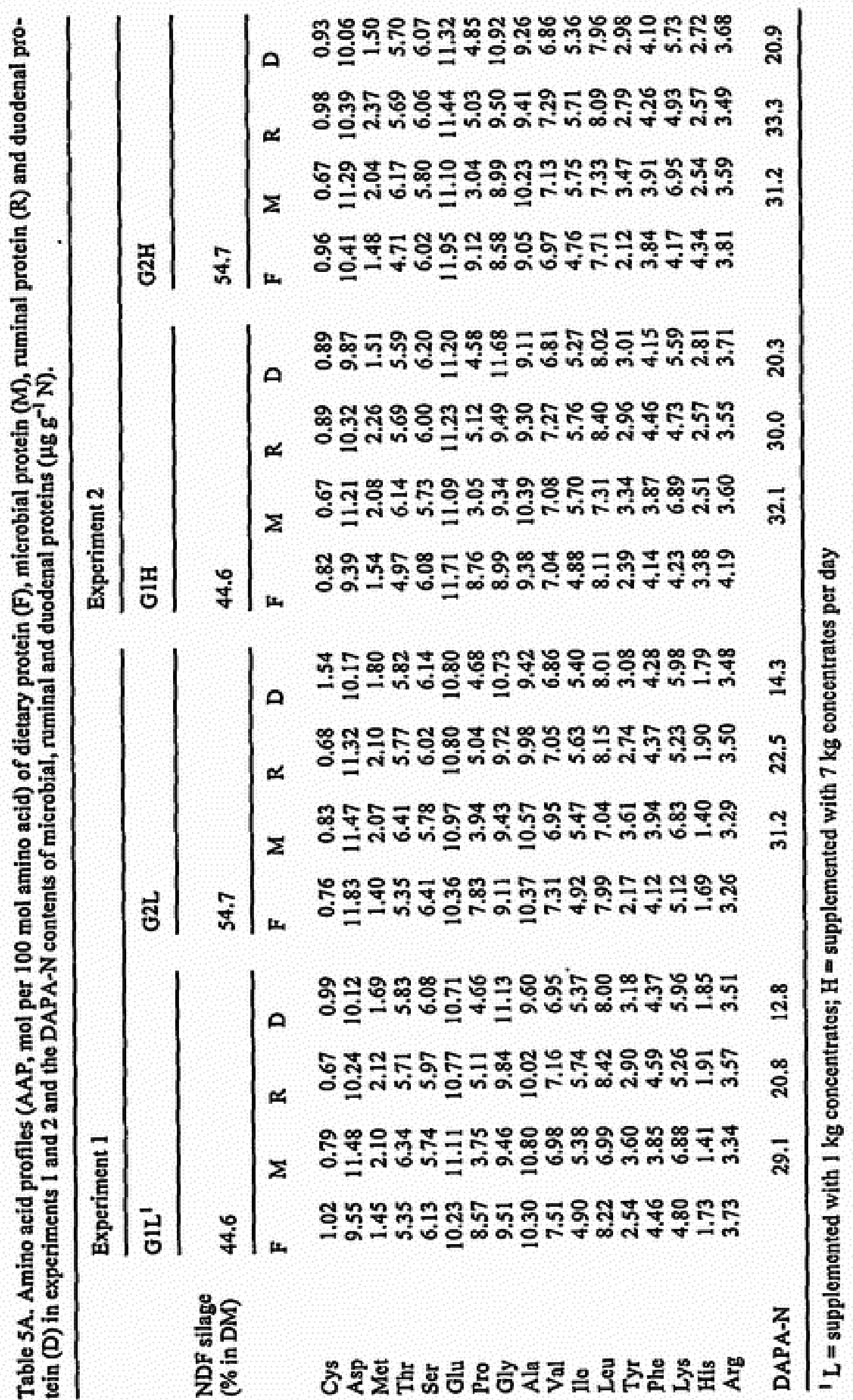




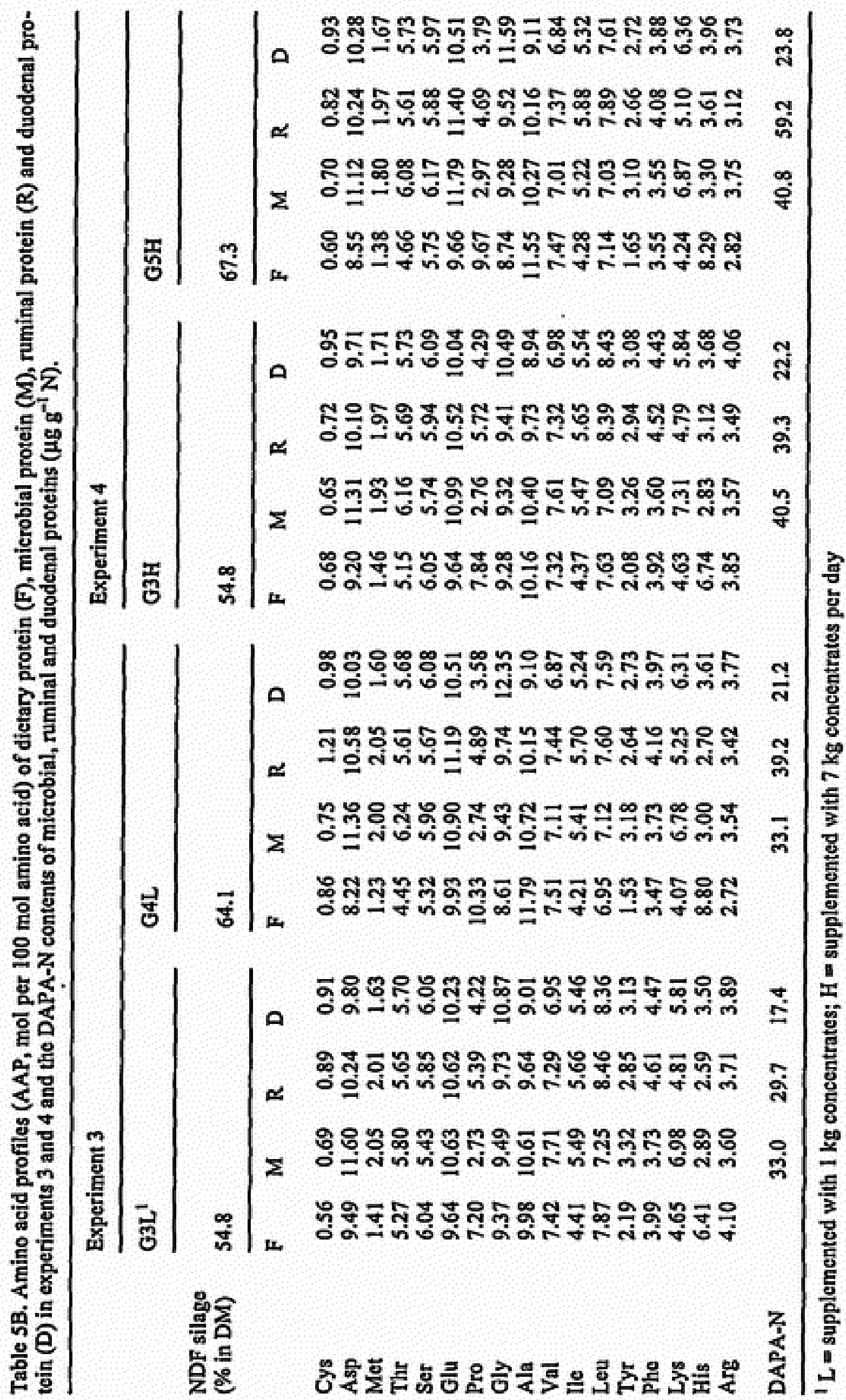


largely responsible for the lag time ( $\left.t^{\prime}\right)$ occasionally observed in $\mathrm{N}$ degradation curves. In our experiments no corrections were made for microbial contamination of the nylon bags. Microbial contamination is proportionally higher for feeds high in cell walls and lower for higher protein feeds (Varvikko \& Lindberg, 1985; Varvikko, 1986). Using a correction for this microbial protein will decrease the $t^{\prime}$ and the degradation pattern of the protein will change. For different feeds, rate of N-disappearance from the nylon bags as well as DM-disappearance was in all cases lower if not corrected for microbial contamination (Varvikko \& Lindberg, 1985). Because of microbial contamination, a lag time was particularly observed for the high roughage diets in their experiments. It may be assumed that during the in situ incubation, not only the feed protein but also microbial protein dissappears from the nylon bag, resulting in a too fast decline of protein in the bags. Thus, if the $k_{d}-C P$ is calculated using a model without a lag-time, the $k_{d}$ might be less biassed due to microbial contamination.

Disappearance rate from the nylon bags of DM and cell wall components was negatively related to the cell wall content of the silages (Bosch et al., 1992a). A decrease in $k_{d}$ for the cell wall fraction makes the protein, which is in the cell contents or associated with the cell walls, less accessible for the bacteria. As a result, the $k_{d}-C P$ was, though not significantly, decreasing with cell wall content of the silages.

The $f_{\mathrm{S}}-\mathrm{CP}$ seemed to increase with cell wall content, except for silage G3, which had an even lower $f_{S}-C P$ than silage G1. Tamminga et al. (1991) showed that the $f_{S^{-}}$ $\mathrm{CP}$ of grass silages in the Netherlands was best described by a regression equation with DM content of the silage and number of days elapsed since May 1st at harvesting. Both factors had a negative effect on $\mathrm{f}_{\mathrm{S}}-\mathrm{CP}$. For the silages used in our experiments, this regression equation predicted the lowest $f_{\mathrm{S}}-C P$ for silage $G 3$, which agrees with our observations.

It is often assumed that the $f_{S}$ is rapidly and fully degraded in the rumen. The $f_{S}$ is likely to have a high degradation rate, but also a higher outflow rate from the rumen. Therefore it does not seem correct to assume a $100 \%$ degradation of $f_{S}$ in the rumen. This overestimation of ruminal degradation is considered to compensate the slight underestimation which may result from microbial contamination. It is, however, not possible to give a precise estimate of the fraction of $f_{S}$ that is escaping rumen fermentation.

According to Bosch et al. (1992b), the $k_{p}$ increases with the cell wall content of a silage. Hence, as shown in Table 4 , the differences in $\mathrm{f}_{\mathrm{E}}$ between silages will be bigger when passage rate is higher for the high cell wall diets than for the low cell wall diets. The higher $f_{E}$ for the high cell wall diets mainly consists of rumen undegradable protein. The rumen undegradable protein fraction is presumed also undegradable in the small intestines (Tamminga et al., 1991), and therefore not available for the animal. The fraction of dietary protein escaping rumen fermentation and digestible in the small intestine is thus higher for the lower cell wall diets.

According to Varvikko (1986) and Susmel et al. (1989), the amino acid composition of the undegraded feed protein can differ considerably from the amino acid composition of the original feed protein. Hof et al. (1990), however, concluded that the AAP of undegraded feed protein hardly differed from the AAP of the original 
protein. If there is a difference between the dietary AAP and the AAP of undegraded feed protein, this would to a certain extent interfere with the AAP method to estimate the fraction of duodenal protein consisting of dietary protein. The AAP of mixed rumen bacteria is determined for every individual animal, and can only interfere with this method if the AAP of duodenal bacteria would differ substantially from rumen bacteria. Outflow rate of rumen fluid is however considerably higher than outflow rate of feed particles. We therefore assumed that the AAP of bacteria isolated from the rumen fluid is representative for duodenal bacteria.

According to Van Soest (1982), the amount of amino acid nitrogen absorbed in the intestines exceeds the dietary intake of nitrogen below about $12.5 \% \mathrm{CP}$ in the diet. The amount of $\mathrm{N}$ entering the duodenum on cell wall rich diets can be considerably higher than the $\mathrm{N}$ intake, whereas on protein rich diets, great losses of $\mathrm{N}$ in the rumen occur. A high fraction of dietary protein escaping rumen fermentation on diets low in protein, still results in a low absolute dietary-N flow to the duodenum. When the $\mathrm{N}$ flow to the duodenum exceeds $\mathrm{N}$ intake, the fraction of duodenal protein originating from the diet will be lower than $f_{E}$.

In general, despite the higher $f_{E}$-values for the high cell wall silages, the fraction of duodenal protein originating from the diet is bound to decrease with cell wall content. An increase in $f_{E}$ with cell wall content, still results in a low dietary protein content in the duodenum, which consists for a higher proportion of indigestible protein.

The $f_{\mathrm{E}}$ of the silages (Table 4) and the $f_{\mathrm{E}}$ of the concentrates (calculated $f_{\mathrm{E}}$ concentrates $=36 \%$, based on the Dutch Feedstuff Table) were multiplied by the intake of silage and concentrate crude protein, respectively, to calculate the amount of dietary protein entering the duodenum. Total protein flow to the duodenum was calculated as the latter value divided by the fraction of dietary protein in duodenal protein (Table 6). Further, duodenal microbial crude protein flow was derived from duodenal dietary crude protein flow and the ratio between microbial and dietary proteins. Finally, a quantity of $2.5 \mathrm{~g}$ endogenous $\mathrm{N}$ was added per $\mathrm{kg}$ dry matter intake (Siddons et al., 1982). The resultant estimates for total duodenal crude protein flow, based on a rate of passage $\left(\mathrm{k}_{\mathrm{p}}\right)$ of $3 \mathrm{\% h}^{-1}$, have been included in Table 6. Compared with the respective quantities ingested with silages and concentrates, nett daily $\mathrm{N}$ losses in the rumen ranged from $-0.04-0.21 \mathrm{~kg} \mathrm{~N}$, and from $0.00-0.17 \mathrm{~kg} \mathrm{~N}$ in early and late lactation, respectively.

The efficiency of microbial protein synthesis seemed lowest for the G1 silage based diets: $25.3-26.1 \mathrm{~g}$ microbial $\mathrm{N}$ per $\mathrm{kg} \mathrm{OM}$ apparently degraded in the rumen (ARDOM, assumed to be $70 \%$ of whole tract digestion). Such values seem a bit low for a situation in the rumen with sufficient energy and protein available. So perhaps, with the lowest cell wall silage, escape of dietary protein from the rumen and, in consequence, rumen microbial protein may have been slightly underestimated. Nevertheless, for the diets based on silages G1, G2 and G3, duodenal N flow was lower compared to the quantities ingested. Though concentrates were added, $\mathrm{N}$ was made available in the rumen in excess of the quantity incorporated in microbial protein. In part, this could be attributed to discontinuous $\mathrm{N}$ release, particularly in the silages with the lower cell wall content. Besides, it seems desirable to provide con- 
INFLUENCE OF STAGE OF MATURITY OF GRASS SILAGES

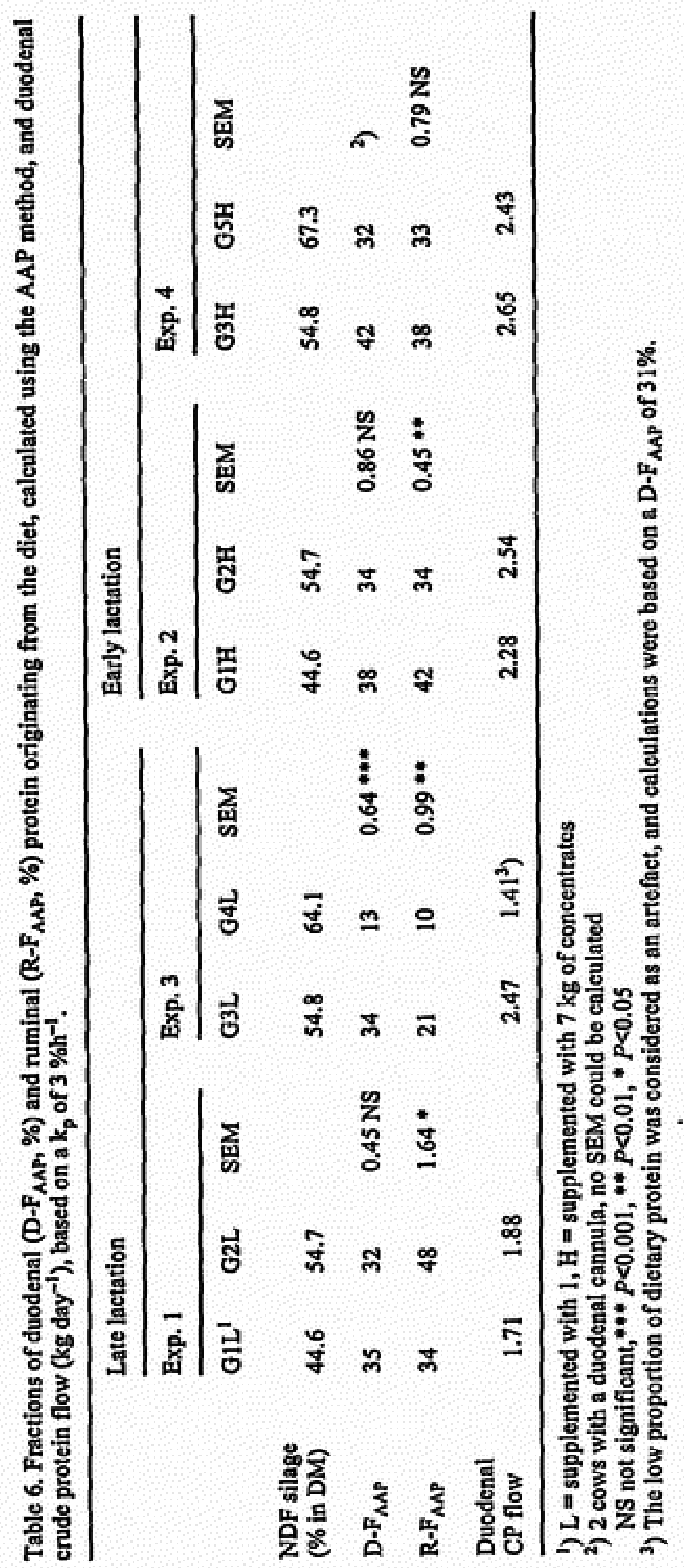




\section{M.W. BOSCH, J. VAN BRUCHEM, L.J.G.M. BONGERS AND S. TAMMINGA}

centrates with less or less easily degradable protein in order to attain a more balanced situation in terms of rumen $N$ (protein) and energy (ARDOM) availability for microbial biomass production. Offering silages high in cell wall content should certainly not be considered as a possible option. Voluntary intake would become considerably lower, and further, with higher cell wall flows the ileal endogenous protein losses increase, resulting in lower apparent protein digestibility in the small intestine and, most probably, a less efficient utilization of the absorbed amino acids (Van Bruchem et al., 1989).

\section{References}

Bosch, M.W., 1991. Influence of stage of maturity of grass silages on digestion processes in dairy cows. Thesis, Agricultural University, Wageningen, The Netherlands.

Bosch, M.W., S. Tamminga, G. Post, C.P. Leffering \& J.M. Muylaert, 1992a. Influence of stage of maturity of grass silages on digestion processes in dairy cows. 1. Composition, nylon bag degradation rates, fermentation characteristics, digestibility and intake. Livestock Production Science 32: 245-264.

Bosch, M.W., S.C.W. Lammers-Wienhoven, G.A. Bangma, H. Boer \& P.W.M. van Adrichem, 1992b. Influence of stage of maturity of grass silages on digestion processes in dairy cows. 2 . Rumen contents, passage rates, distribution of rumen and faecal particles and mastication activity. Livestock Production Science 32:265-281.

Hof, G., W.J.A. Kouwenberg \& S. Tamminga, 1990. The effect of washing procedure on the estimation of the in situ disappearance of amino acids from feed protein. Netherlands Journal of Agricultural Science 38:719-724.

Mehrez, A.Z. \& E.R. Orskov, 1977. A study of the artificial fibre bag technique for determining the digestibility of feeds in the rumen. Journal of Agricultural Science 88:645-650.

Meyer, R.M., E.E. Bartley, C.W. Deyoe \& V.F. Colenbrander, 1967. Feed processing. 1. Ration effects on rumen microbial protein symthesis and amino acid composition. Journal of Dairy Science 50: 1327-1331.

Moore, S., 1963. On the determination of cystin as cysteic acid. Journal of Biology and Chemistry 238:235-237.

Nocek, J.E. \& A.L. Grant, 1987. Characterization of in situ nitrogen and fiber digestion and bacterial nitrogen contamination of hay crop forages preserved at different dry matter percentages. Journal of Animal Science 64:552-564.

Siddons, R.C., D.E. Beever \& J.V. Nolan, 1982. A comparison of methods for the estimation of microbial nitrogen in duodenal digesta of sheep. British Journal of Nutrition 48:377-389.

SPSS Inc., 1988. SPSS/PC+ Base manual. SPSS Inc., Chicago. Illinois.

Susmel, P., B. Stefanon, C.R. Mills and M. Candido, 1989. Change in amino acid composition of different protein sources after rumen incubation. Animal Production 49:375-383.

Tamminga, S., 1981. Nitrogen and amino acid metabolism in dairy cows. Doctoral Thesis, Agricultural University, Wageningen, the Netherlands.

Tamminga, S., R. Ketelaar \& A.M. van Vuuren, 1991. Degradation of nitrogenous compounds in conserved forages in the rumen of dairy cows. Grass and Forage Science 46:427-435.

Van Bruchem, J., S.M.G. Rouwers, G.A. Bangma, S.C.W. Lammers-Wienhoven \& P.W.M. van Adrichem, 1985. Digestion of proteins of varying degradability in sheep. 2. Amount and composition of the protein entering the small intestine. Netherlands Journal of Agricultural Science 33:273-284.

Van Bruchem, J., L.J.G.M. Bongers, S.C.W. Lammers-Wienhoven, G.A. Bangma \& P.W.M. van Adrichem, 1989. Apparent and true digestibility of protein and amino acids in the small intestine of sheep as related to the duodenal passage of protein and non-protein dry matter. Livestock Production Science 23:317-327.

Van Soest, P.J., 1982. Nutritional ecology of the ruminant. O\&B Books Inc., Corvallis, OR. 


\section{INFLUENCE OF STAGE OF MATURITY OF GRASS SILAGES}

Van Vuuren, A.M. \& J.A.C. Meijs, 1987. Effects of herbage composition and supplement feeding on the excretion of nitrogen in dung and urine by grazing dairy cows. In: H.G. van der Meer, R.J. Unwin, T.A. van Dijk \& G.C. Ennik (Eds), Animal manure on grassland and fodder crops. Fertilizer or waste? Martinus Nijhoff Publishers, Dordrecht, the Netherlands, pp. 17-25.

Varvikko, T. \& J.E. Lindberg, 1985. Estimation of microbial nitrogen in nylon-bag residues by feed ${ }^{15} \mathrm{~N}$ dilution. British Journal of Nutrition 54:473-481.

Varvikko, T., 1986. Microbially corrected amino acid composition of rumen-undegraded feed protein and amino acid degradability in the rumen of feeds enclosed in nylon bags. British Journal of Nutrition 56:131-140. 